\title{
Spermatogenesis in sheep supplemented with detoxified castor bean (Ricinus communis L.) as a replacement for soybean meal
}

\author{
Espermatogênese de ovinos suplementados com torta de mamona (Ricinus communis \\ L.) destoxificada em substituição ao farelo de soja
}

ROCHA, Laiara Fernandes ${ }^{1}$

https://orcid.org/0000-0002-0438-0958

RIBEIRO, Márcio de Oliveira ${ }^{1}$

https://orcid.org/0000-0002-8784-0023

SANTANA, Ana Lúcia Almeida ${ }^{1}$

https://orcid.org/0000-0003-3504-6992

JESUS, Ronival Dias Lima de ${ }^{1}$

https://orcid.org/0000-0002-4380-5218
SOUZA, Rosiléia Silva ${ }^{1}$

https://orcid.org/0000-0003-4997-9048

BAGALDO, Adriana Regina ${ }^{1}$

https://orcid.org/0000-0001-5800-7609

ARAÚJO, Fabiana Lana de ${ }^{1}$

https://orcid.org/0000-0001-5973-2861

BARBOSA, Larissa Pires ${ }^{1 *}$

https://orcid.org/0000-0002-1473-4991

${ }^{1}$ Federal University of Recôncavo of Bahia, Center for Agrarian, Environmental and Biological Sciences, Cruz das Almas, Bahia, Brazil.

*larissa@ufrb.edu.br

\section{RESUMO}

O objetivo com este estudo foi avaliar o efeito da substituição do farelo de soja pela torta de mamona destoxificada sobre a espermatogênese em ovinos. Foram utilizados 24 ovinos, com peso médio de $29 \pm 0,8 \mathrm{~kg}$ e 9 meses de idade, distribuídos aleatoriamente em três tratamentos: $\mathrm{T} 1=0 \%, \mathrm{~T} 2=50 \%$ e T3 $=100 \%$ de substituição do farelo de soja pela torta de mamona destoxificada. Os animais foram alimentados com pastagem de capim Aruana (Panicum maximum cv. Aruana) e ração durante 90 dias. Por ocasião do abate, coletou-se os testículos para mensurações e avaliação da espermatogênese. Os dados foram avaliados quanto à normalidade por meio do teste de Shapiro-Wilk e utilizou-se a Análise de Variância com 5\% de significância. Não houve efeito da substituição do farelo de soja pela torta de mamona destoxificada nos níveis testados $(\mathrm{P}>0,05)$ para nenhuma das variáveis avaliadas. O rendimento médio da espermatogênese foi de 72,91 espermátides arredondadas produzidas a partir de uma espermatogônia; a média do número total de células germinativas sustentadas por uma de célula de Sertoli foi 12,09; a média da reserva espermática testicular total foi de $31,82 \times 10^{9}$ e de $238,28 \times 10^{6}$ por grama de testículo; a média da produção espermática diária foi de $3,03 \times 10^{9}$ e de $22,69 \times 10^{6}$ por grama de testículo e o número total de células de Sertoli foi de $4,15 \times 10^{9}$ e de $34,51 \times 10^{6}$ por grama de testículo. Os resultados demonstram que é possível substituir 
$100 \%$ do farelo de soja pela torta de mamona destoxificada na dieta de ovinos sem prejuízos no processo de espermatogênese.

Palavras-chave: Células de Sertoli, morfometria testicular, produção espermática

\begin{abstract}
The objective was to evaluate the effect of replacing soybean meal with the detoxified castor bean cake on testicular morphometry and spermatogenesis of sheep. Were used 24 uncastrated, 9-month old sheep weighing $29 \pm 0.8 \mathrm{~kg}$ they were randomly distributed among three treatments: $\mathrm{T} 1=0 \%, \mathrm{~T} 2=50 \%$, and $\mathrm{T} 3=100 \%$ substitution of soybean meal with detoxified castor bean cake. The animals were fed with Aruana grass pastage (Panicum maximum 'Aruana') and a ration for 90 days. After slaughtering, the testicles were collected and histological slides were prepared with tissue fragments. The data were evaluated for normality using the Shapiro-Wilk test, and analysis of variance was carried out at 5\% level of significance. Substitution of soybean meal with detoxified castor bean cake had no effect on any of the assessed variables at the tested levels $(P>0.05)$. The mean yield of spermatogenesis was 72.91 rounded spermatids per spermatogonium; the mean of total number of germ cells held by a Sertoli cell was 12.09; the mean of the testicular spermatic reserve was $31.82 \times 10^{9}$ and that per testicular gram was $238.28 \times 10^{6}$; the mean of daily spermatic production was $3.03 \times 10^{9}$ and that per testicular gram was $22.69 \times 10^{6}$; and the total number of Sertoli cells was $4.15 \times 10^{9}$ and that per testicular gram was $34.51 \times 10^{6}$. The results show that it is possible to replace $100 \%$ of the soybean meal with detoxified castor bean cake in sheep diet without any effects on spermatogenesis; however, it is important to perform seminal evaluations in future studies.
\end{abstract}

Keywords: Sertoli cells, sperm production, testicular morphometry

\section{INTRODUCTION}

Animal feeding represents a bigger proportion of the production cost, this on account of the high prices of the traditionally used concentrated feed. This drives research focused on alternative foods, with the main goal of reducing this cost without changing parameters such as weight gain, carcass quality, reproductive performance (Santos et al., 2016).

One of the alternative to reduce the cost of animal feed is via the use of byproducts of biofuel production. Silva et al. (2015) proposed castor beans to be one of the most suitable oilseeds for the production of biofuel in northeastern Brazil, because of their ability to produce in water shortage, can be used in consortium with other crops, and in family farming production systems, besides being popular with consumers and therefore having high market value. Sub-products of castor bean obtained after oil extraction can potentially be used in the preparation of animal feed, because of their considerable protein content, low cost, and ease of use (Sousa et al., 2017). Besides, the exploitation of waste products generated by industries prevents them from being released directly into the environment (Santos et al., 2016). However, presence of antinutritional factors in the endosperm of the castor bean seeds, limits the exploitation of this sub-product for animal feeding (Souza et al., 2018).

Among the toxic principles present in castor bean, ricin is considered the most 
lethal substance (composed of two subunits $(36 \mathrm{kDa})$ and $\mathrm{B}(29 \mathrm{kDa})$ linked by bridges disulfídic) and a pretreatment such as detoxification by autoclaving and calcium hydroxide solution is necessary when the seed is intended for animal feeding; ricin can be entirely eliminated via this process (Gomes et al., 2017).

In this way it is necessary to evaluate the reproductive characteristics in the animals fed with detoxified castor bean cake in order to investigate its effects on reproduction. One of the methods by which this assessment can be performed is testicular morphometry. According to Azevedo et al. (2010), the intrinsic yield of spermatogenesis and supporting capacity of Sertoli cells are the desirable indicators of sperm production in a species.

Therefore, the objective of the present study was to evaluate the effects of substitution of soybean meal with detoxified castor bean cake on the testicular morphometry and spermatogenesis of sheep.

\section{MATERIALS AND METHODS}

This study was performed in the experimental farm of the Center for Agrarian, Environmental, and Biological Sciences of the Federal University of Reconcavo of Bahia-UFRB, in the town Cruz das Almas-Bahia. The town is characterized by a hot and humid tropical climate, according to the Köppen classification, and an annual average rainfall of $1.224 \mathrm{~mm}$. The relative air humidity is approximately $74 \%$ and the annual average temperature is $24.8{ }^{\circ} \mathrm{C}$ (INMET, 2014).

The procedures performed in this study were approved by the Committee on Ethics and Use of Animals (CEUA) of the UFRB, following protocol number 23007.003064/2014-10.

Were used 24 non-castrated male sheep, of the Santa Inês and the Dorper mixed race, nine-month-old and an average weight of $29 \pm 0.8 \mathrm{~kg}$, distribuited in a completely randomized design in three treatments, containing varying levels of detoxified castor bean cake in the diet as a substitute for soybean meal, where, T1 $=0 \%$ (control), $\mathrm{T} 2=50 \%$, and $\mathrm{T} 3=$ $100 \%$ substitution. The castor bean cake used as a substitute for soybean meal was subjected to the detox process using calcium oxide (Oliveira et al., 2010).

The duration of the experimental period was 90 days, among which the animals were acclimatized during the initial 15day period. During the experimental period, the animals had access to a pasture of Aruana (Panicum maximum 'Aruana') and received dietary supplementation at a proportion of $1.2 \%$ of their live weight once a day (07:00 h); the diets were formulated to be isonitrogenated (NRC, 2007) (Table 1). Water was provided ad libitum. 
Table 1. Composition of the diets used and the bromatological composition

\begin{tabular}{lllll}
\hline \multirow{2}{*}{ Ingredients } & \multicolumn{4}{l}{ Replacement levels of castor cake } \\
\cline { 2 - 5 } & Pasture & $0 \%$ & $50 \%$ & $100 \%$ \\
\hline Soybean meal & & 33.2 & 16.5 & - \\
Ground corn & 63.5 & 59.7 & 63.5 \\
Castor cake & - & 20.3 & 32.0 \\
Urea (9:1 U:SA) & 1.3 & 1.5 & 2.5 \\
Salt & 2.0 & 2.0 & 2.0 \\
Total & 100.00 & 100.00 & 100.00 \\
\hline Bromatological composition & & & & \\
\hline Dry matter & 29.86 & 88.34 & 88.63 & 88.82 \\
Crude protein & 7.30 & 26.03 & 26.19 & 26.20 \\
Neutral detergent fiber & 78.73 & 13.68 & 21.57 & 25.91 \\
Total digestible nutrients & 56.92 & 82.11 & 80.59 & 79.26 \\
\hline
\end{tabular}

After the supplementation period (90 days), the animals were weighted and sent for slaughtering in an inspected refrigerator. After the slaughter, the testicles were collected, identified, and transferred to the Animal Reproduction Laboratory of the UFRB, where weighing and measurements were performed. From an average portion of the right testicle of each animal, fragments with an approximate thickness of $5 \mathrm{~mm}$ and length of $10 \mathrm{~mm}$ were removed to slide preparation.

To obtain the histological slides, the fragments were fixed in buffered formol for $24 \mathrm{~h}$ and then transferred to $70 \%$ alcohol, in which the fragments remained until slide preparation. The fragments were subjected to serial ethanol dehydration $(70 \%, 80 \%, 90 \%$ and absolute), with concentration being changed every 30 minutes, and incubated in 2-hydroxyethyl methacrylate solution (Historesina Leica $^{\mathrm{TM}}$, Lab House, Minas Gerais, Brazil). Sections (3- $\mu \mathrm{m}$ thick) were obtained through semi-serial cuts in a rotating microtome (RM 2255, Leica $^{\mathrm{TM}}$, Lab House, Minas Gerais, Brazil) using glass razor and then stained with $1 \%$ sodium toluidine borate blue for $25 \mathrm{~s}$.

\section{Spermatogenic yield}

In each histological slide, were evaluated five transverse sections of seminiferous tubules in stage 1 of the seminiferous epithelium cycle (SEC); the ones that presented the most circular contours were chosen by horizontal sweep, to obtain values for the following variables: cellular population of the seminiferous epithelium; intrinsic spermatogenic yield; Sertoli cell index; diameter of the cross-sectional area of the seminiferous tubules and the nucleus, and the nuclei of spermatogenic lineage; testicular spermatic reserve per testis and per gram of testis; and daily spermatic production based on the histological quantity of the sample taken from each testis.

To estimate the cellular population of the seminiferous epithelium, different types of nuclei of the spermatogenic lineage were counted, in addition to the nucleoli of the Sertoli cells, using a Nikon ${ }^{\mathrm{TM}}$ microscope coupled with micrometric eyepiece, magnified by 40x. The following types of cells were counted: Spermatogonia type A; primary preleptotene/leptotene spermatocytes; primary spermatocytes in pachytene; and rounded spermatids and Sertoli cells. 
The number of each type of cells was corrected with the average nuclear diameter and cutting thickness (Amann \& Almquist, 1962). Because the Sertoli cells have irregular nuclei, the correction was carried out using the mean nucleolar diameter (MND), obtained by the diameter measurements of 10 nuclei studied in stage 1 of SEC, in each animal. After measuring the tubular diameter, and that of the nuclei and nucleoli of the cells, values were corrected by magnifying the micrometric eyepiece by 40x. Then were performed the conversions using the following scale: 1 trace of the micrometric ruler equals 1 $\mu \mathrm{m}$ in the 100x objective, $2.5 \mu \mathrm{m}$ in the 40x objective, and $10 \mu \mathrm{m}$ in the $10 \mathrm{x}$ objective, and for the corrective factor was applied to the 40x eyepiece ( 1 trace $=2.5 \mu \mathrm{m})$, and then multiplied by 10 , to obtain the values in $\mu \mathrm{m}$.

The intrinsic yield of spermatogenesis was determined using the reasons between the corrected cell numbers, obtained by transverse section of the tubule in stage 1 of SEC. Based on them, the following parameters were calculated: Efficiency coefficient of spermatogonial mitoses (reason between the number of primary spermatocytes in pre-leptotene/leptotene and the number of spermatogonia type $\mathrm{A}-\mathrm{A} / \mathrm{PL}$ ); Meiotic yield (between the number of rounded spermatids and the number of primary spermatocytes in pachytene PQ/Ar); General spermatogenic yield (between the number of rounded spermatids and the number of spermatogonia type $\mathrm{A}-\mathrm{A} / \mathrm{Ar}$ ); Occurrence of cell loss during the meiotic prophase: reason between the number of primary spermatocytes in preleptotene/leptotene and the number of primary spermatocytes in pachytene PL/PQ).
The Sertoli cell index were determined to represent the relation between the corrected numbers of sperm cells and Sertoli cells in stage 1 of SEC. The following parameters were calculated: Spermatogonia type A/Sertoli cells (S/A); Primary pre-leptotene/leptotene spermatocytes/Sertoli cells (S/PL); Primary spermatocytes in pachytene/Sertoli cells (S/PQ); Rounded spermatids/Sertoli cells (S/Ar); Total of germinated cells/Sertoli cells (S/SG).

The population of Sertoli cells was calculated based on their production per testicle and per gram of testicle, and the corrected numbers of nucleoli of Sertoli cells from the transverse sections and total length of seminiferous tubule, were estimated according to Hochereau-deReviers \& Lincoln (1978).

Testicular spermatic reserve (TSR) was calculated to estimate the total spermatic reserve per gram, based on the histological quantity (Morais et al., 2016). Daily spermatic production (DSP) was calculated as the histological quantity of testicles, according Amann \& Almquist (1962).

The data were evaluated for normality according to the Shapiro Wilk test. The variables presented normal distribution, and thus, analysis of variance were performed at 5\% level of significance, using SPSS program version 13.1 (1989-2012).

\section{RESULTS}

Replacing soybean meal with detoxified castor bean cake had no effect $(\mathrm{P}>0.05)$ on the populations of different cell types, evaluated from the transverse section of seminiferous tubule in stage 1 of SEC (Table 2). On average, $0.84 \pm 0.33$ spermatogonia type A, $12.79 \pm 4.25$ spermatocytes in pre- 
leptotene/leptotene, $\quad 14.80 \pm 4.06$

spermatocytes in pachytene, $48.42 \pm 17.69$ rounded spermatids, and
$6.59 \pm 1.37$ Sertoli cells were observed per transverse section of the seminiferous tubule.

Table 2. Cell population corrected for the stage 1 seminiferous epithelium (SEC) of sheep supplemented with detoxified castor bean cake replacing soybean meal

\begin{tabular}{lllll}
\hline \multirow{2}{*}{ Variables } & \multicolumn{4}{c}{ Replacement levels of castor cake } \\
\cline { 2 - 5 } & $0 \%$ & $50 \%$ & $100 \%$ & P value \\
\hline $\mathrm{A}^{\mathrm{a}}$ & $0.81 \pm 0.09$ & $0.64 \pm 0.21$ & $1.08 \pm 0.70$ & 0.11 \\
$\mathrm{PL}^{\mathrm{b}}$ & $13.67 \pm 4.09$ & $13.53 \pm 2.96$ & $11.18 \pm 5.69$ & 0.49 \\
$\mathrm{PQ}^{\mathrm{c}}$ & $15.16 \pm 5.35$ & $14.38 \pm 2.95$ & $14.87 \pm 3.90$ & 0.93 \\
$\mathrm{Ar}^{\mathrm{d}}$ & $53.47 \pm 16.3$ & $50.59 \pm 8.72$ & $41.20 \pm 28.33$ & 0.44 \\
$\mathrm{~S}^{\mathrm{e}}$ & $6.76 \pm 0.84$ & $6.17 \pm 1.11$ & $6.84 \pm 2.17$ & 0.59 \\
\hline
\end{tabular}

The values described correspond to the mean \pm standard deviation of type cells: ${ }^{a} \mathrm{~A}$ spermatogonia; ${ }^{\mathrm{b}}$ primary spermatocytes in pre-leptotene/leptotene; ${ }^{\mathrm{c}}$ primary spermatocytes in pachytene; ${ }^{\mathrm{d}}$ rounded spermatids; ${ }^{\mathrm{e}}$ Sertoli cells.

The intrinsic spermatogenesis performance was also not affected by the replacement of soybean meal with detoxified castor bean cake in the sheep $\operatorname{diet}(\mathrm{P}>0.05)$ (Table 3). The coefficient average showed that PL produced by an
A-type spermatogonia was $19.11 \pm 7.01$. The average cell loss during the meiotic prophase was $1.14 \pm 0.21$. The average meiotic performance showed that $\mathrm{Ar}$ produced by PQ was $3.41 \pm 0.70$.

Table 3. Intrinsic spermatogenesis yield of sheep supplemented with detoxified castor bean cake replacing soybean meal

\begin{tabular}{lllll}
\hline \multirow{2}{*}{ Variables } & \multicolumn{4}{c}{ Replacement levels of castor cake } \\
\cline { 2 - 5 } & $0 \%$ & $50 \%$ & $100 \%$ & P value \\
\hline $\mathrm{A} / \mathrm{PL}^{\mathrm{a}}$ & $16.98 \pm 4.93$ & $22.90 \pm 7.88$ & $17.44 \pm 8.23$ & 0.19 \\
$\mathrm{PL} / \mathrm{PQ}^{\mathrm{b}}$ & $1.10 \pm 0.17$ & $1.08 \pm 0.20$ & $1.24 \pm 0.26$ & 0.32 \\
$\mathrm{PQ} / \mathrm{Ar}^{\mathrm{c}}$ & $3.61 \pm 0.50$ & $3.56 \pm 0.39$ & $3.06 \pm 1.20$ & 0.33 \\
$\mathrm{~A} / \mathrm{Ar}{ }^{\mathrm{d}}$ & $65.99 \pm 18.71$ & $85.95 \pm 29.76$ & $66.79 \pm 32.38$ & 0.26 \\
\hline
\end{tabular}

The values described correspond to the mean \pm standard deviation of the: ${ }^{\text {a }}$ spermatocyte preleptotene/leptotene ratios and A-type spermatogonia; ${ }^{b}$ spermatocytes in pre-leptotene/leptotene and spermatocytes in pachytene; ${ }^{\mathrm{c}}$ round spermatids and spermatocytes in pachytene; ${ }^{\mathrm{d}}$ rounded spermatids and A-type spermatogonia.

With the goal of evaluating the Sertoli cells index, were designated reasons between the number of cells of spermatogenic lineage and Sertoli cells (Table 4). There was no difference between treatments $(\mathrm{P}>0.05)$. The mean of Sertoli cells: Spermatogonia type A was $0.11 \pm 0.02$; Sertoli cells/preleptotene/leptotene spermatocytes was $2.02 \pm 0.71$; Sertoli cells/spermatocytes in pachytene was $2.26 \pm 0.79$; and Sertoli cells/rounded spermatids was $7.7 \pm 2.67$. 
Table 4. Sertoli cell index of sheep supplemented with detoxified castor bean cake replacing soybean meal

\begin{tabular}{lllll}
\hline \multirow{2}{*}{ Variables } & \multicolumn{3}{c}{ Replacement levels of castor cake } \\
\cline { 2 - 5 } & $0 \%$ & $50 \%$ & $100 \%$ & P value \\
\hline $\mathrm{S} / \mathrm{A}^{\mathrm{a}}$ & $0.12 \pm 0.02$ & $0.10 \pm 0.02$ & $0.10 \pm 0.02$ & 0.17 \\
$\mathrm{~S} / \mathrm{PL}{ }^{\mathrm{b}}$ & $2.08 \pm 0.78$ & $2.25 \pm 0.67$ & $1.74 \pm 0.68$ & 0.47 \\
$\mathrm{~S} / \mathrm{PQ}^{\mathrm{c}}$ & $2.33 \pm 1.07$ & $2.41 \pm 0.76$ & $2.05 \pm 0.55$ & 0.75 \\
$\mathrm{~S} / \mathrm{Ar}^{\mathrm{d}}$ & $8.12 \pm 3.00$ & $8.42 \pm 2.08$ & $6.54 \pm 2.95$ & 0.45 \\
$\mathrm{~S} / \mathrm{CG}^{\mathrm{e}}$ & $12.64 \pm 4.71$ & $13.19 \pm 3.27$ & $10.43 \pm 3.93$ & 0.48 \\
\hline
\end{tabular}

The values described correspond to the mean \pm standard deviation of the ratios between: ${ }^{a}$ spermatogonia type A and Sertoli cells; ${ }^{b}$ pre-leptotene/leptotene primary spermatocytes and Sertoli cells; ${ }^{\mathrm{c}}$ primary spermatocytes in pachytene and Sertoli cells; ${ }^{\mathrm{d}}$ rounded spermatids and Sertoli cells; ${ }^{\mathrm{e}}$ total germ cell and Sertoli cells.

There was no difference in daily spermatic production, total number of Sertoli cells, and testicular spermatic reserve per testicle and per gram of testicular parenchyma, between treatments $(\mathrm{P}>0.05)$ (Table 5). The mean of total number of Sertoli cells was $4.15 \pm 0.94 \times 10^{9}$ and that per gram of testicle was $34.52 \pm 11.44 \times 10^{6}$. The average daily spermatic production was $3.02 \pm 1.21 \times 10^{9}$ and that per testicular gram was $22.69 \pm 5.21 \times 10^{6}$. The average testicular spermatic reserve was $31.82 \pm 12.7 \times 10^{9}$ and that per testicle gram was $238.28 \pm 54.77 \times 10^{6}$.

Table 5. Estimates of sperm production and total Sertoli cells per gram of testis, calculated from the analysis of the testicular histology of sheep supplemented with detoxified castor bean cake replacing soybean meal

\begin{tabular}{|c|c|c|c|c|}
\hline \multirow[t]{2}{*}{ Variables } & \multicolumn{3}{|c|}{ Replacement levels of castor cake } & \multirow[b]{2}{*}{$P$ value } \\
\hline & $0 \%$ & $50 \%$ & $100 \%$ & \\
\hline $\operatorname{NSCT}^{\text {a }}\left(\mathrm{x} 10^{9}\right)$ & $4.43 \pm 1.34$ & $3.99 \pm 0.85$ & $4.02 \pm 0.64$ & 0.64 \\
\hline $\mathrm{NSCT} / \mathrm{g}^{\mathrm{a}}\left(\mathrm{x} 10^{6}\right)$ & $34.08 \pm 11.72$ & $29.60 \pm 5.08$ & $39.87 \pm 17.51$ & 0.31 \\
\hline $\operatorname{DSP}^{\mathrm{b}}\left(\mathrm{x} 10^{9}\right)$ & $3.32 \pm 1.54$ & $3.15 \pm 0.78$ & $2.60 \pm 1.30$ & 0.59 \\
\hline $\mathrm{DSP} / \mathrm{g}^{\mathrm{b}}\left(\mathrm{x} 10^{6}\right)$ & $23.99 \pm 4.83$ & $23.07 \pm 3.87$ & $21.00 \pm 6.93$ & 0.57 \\
\hline $\operatorname{TSR}^{\mathrm{c}}\left(\mathrm{x} 10^{9}\right)$ & $34.95 \pm 16.22$ & $33.12 \pm 8.21$ & $27.38 \pm 13.66$ & 0.59 \\
\hline $\mathrm{TSR} / \mathrm{g}^{\mathrm{c}}\left(\mathrm{x} 10^{6}\right)$ & $251.99 \pm 50.78$ & $242.29 \pm 40.73$ & $220.57 \pm 72.81$ & 0.57 \\
\hline
\end{tabular}

The values described correspond to the mean \pm standard deviation of the: ${ }^{a}$ number of Sertoli cells (NSCT) total and per gram; bdaily sperm production (DSP) total and per gram; ${ }^{c}$ testicular spermatic reserve (TSR) total and per gram.

\section{DISCUSSION}

Among the treatments, similarities in the populations of spermatogonia type A, primary spermatocytes in preleptotene/leptotene and pachytene, rounded spermatids, in addition to the Sertoli cells, indicate that $100 \%$ substitution of soybean meal with detoxified castor bean cake does not affect spermatogenesis and, consequently, the germinating cell populations.

The average number of spermatogonia type A obtained in the present study in the group that consumed $100 \%$ of the 
castor bean cake, is similar to the result reported by Oliveira et al. (2015), when fourteen-month-old breeding goats were fed a supplementary diet in the presence $(1.2 \pm 0.04 \mathrm{~A})$ and absence $(1.3 \pm 0.1 \mathrm{~A})$ of castor bean cake containing $50 \mathrm{mg} / \mathrm{kg}$ of ricin. However, the mean of primary spermatocytes in different phases of development was inferior to the values observed by Martins et al. (2008) when spermatogenesis parameters were evaluated $(36.7 \pm 9.5$ spermatocytes in PQ) in thirteen-month-old SRD sheep, and by Oliveira et al. (2015) when soybean meal was replaced with the undetoxified castor bean cake in the goat $\operatorname{diet}(21.2 \pm 0.2$ spermatocytes in PQ).

This difference between the studies may be justified by the cell loss that naturally occurs in the spermatogonal division phase, since there was no replacement effect between treatments. Besides, the age difference between the animals used may have influenced the results, because according to Billig et al. (1995) one of the factors that may cause cell loss is related to the developmental stage of an animal.

Similar to the germinative lineage cells, the Sertoli cell population, did not change depending on the diets. According to Billig et al. (1995), the Sertoli cell population can vary depending on three principal factors: developmental stage of the animal; hormonal fluctuation, particularly follicle-stimulating hormone (FSH), which acts directly on the Sertoli cells; and the specific stage of SEC. Such factors may justify the difference observed between the values observed in the present study and those reported by Martins et al. (2008), who obtained average of $8.3 \pm 1.5$ Sertoli cells in thirteen-month-old SRD sheep.
It is valid to emphasize that, besides the factors linked to the animals, such as age, the difference in spermatogenic yield between the studies can also be justified by the method used. In this study, evaluation of the germinating cells was performed in stage 1 of SEC, as described by Oliveira et al. (2015), meanwhile in the studies carried out by other researchers, such as Martins et al. (2008), the evaluations were performed in sections, in stages 1, 2, and 8 of SEC.

The efficiency coefficient of spermatogonals mitosis was determined based on the reason between the number of primary spermatocytes in preleptotene/leptotene and the number of spermatogonia type A (A/PL). The average of $\mathrm{A} / \mathrm{PL}$ is within the range of parameters observed in most of the domestic animals (14.6 to 24.8), as described by França \& Russel (1998). If this coefficient was $100 \%$, one spermatogonia type A would produce 64 PL; however, most of the cell loss occurs during this mitotic phase and the efficiency of the spermatogonal mitosis rarely comes to $100 \%$. In this study, $70.31 \%$ of cell loss was observed; this was also within the range of means (7080) observed in most animals (França \& Russell, 1998).

To evaluate the concurrency of cell loss with meiotic prophase, the reason between the number of spermatocytes in pre-leptotene/leptotene and spermatocytes in pachytene (PL/PQ) was calculated. The result demonstrated that there was no significant loss during this phase, because one primary spermatocyte in pre-leptotene/leptotene is expected to produce one primary spermatocyte in pachytene.

Meiotic yield is associated with the efficiency of meiotic divisions during the spermatogenic process and was 
determined based on the number of rounded spermatids produced for a given number of spermatocytes in pachytene (PQ/Ar). If meiotic yield were $100 \%$, each PQ would produce four Ar. In this study, efficiency of meiotic divisions was observed to be $85.25 \%$, which is within the expected limit reported for domestic animals, because according to França \& Russell (1998), the efficiency is expected to be $70 \%$, and about $30 \%$ of loss may occur in this phase. In most mammals, these losses result from defective cells elimination mechanism.

The general yield of spermatogenesis estimates the production capacity of general spermatogenic process. This is calculated as the number of rounded spermatids produced per spermatogonium type A (A/Ar) per transverse section of the seminiferous tubule, and the mean yield obtained $(72.91 \pm 26.95)$ is within the expected range observed in most domestic species (37.4 and 74.2 Ar per A) (França \& Russell, 1998). Using this parameter as an indicator of spermatozoa production is justified, because losses occurring during the spermatogenic process are considered insignificant, which means that the number of rounded spermatids is considered as the spermatozoa population (Johnson, 2000).

In the present study, as opposed to the $256(100 \%)$ rounded spermatids expected, $72.91 \quad(28.48 \%)$ were observed, indicating $71.5 \%$ cell loss during all the process. Although this loss is considerable, it is within the expected range observed in most domestic animals. According to França \& Russell, only 15 to $50 \%$ of the expected number spermatozoa are actually produced.

The reason observed between germinating cells and Sertoli cells provides an estimate of the latter's carrying capacity. Martins et al. (2008), observed $0.30 \pm 0.10$ spermatogonia per Sertoli cells after evaluating spermatogenesis in thirteen-month-old SRD sheep, higher than that found in this study $(0.11 \pm 0.02)$. This indicates that the support of the Sertoli cells in the beginning of the spermatogenic process observed in the present study is greater than that observed in the consulted reports, showing that castor bean cake, when detoxified, can be used for animal feeding without the risk of hindering the Sertoli cells index.

The reason between Sertoli cells and spermatocytes in pre-leptotene/leptotene obtained $(2.02 \pm 0.71)$ may explain the efficiency coefficients of spermatogonial mitosis; the cell loss that occurred in this phase was because the number of primary spermatocytes in preleptotene/leptotene was adequate for Sertoli cells to sustain.

The data obtained in the present study reasons between Sertoli cells and spermatocytes in pachytene are smaller than the data reported; Martins et al. (2008) observed 4.8 \pm 1.6 PQ per $\mathrm{S}$ in SRD sheep. However, such divergence between studies may be justified, because, during the spermatogonial division phase, greater cell loss occurs in most domestic animals, which, according to França \& Russel (1998), is due to the defective cell elimination mechanism.

The mean reason found in this study between Sertoli cells and rounded spermatids was $7.7 \pm 2.67$. According to França \& Russel (1998), number of spermatids per Sertoli cell is the most important index for estimating the spermatic efficiency of an animal. Based on this index, one can infer that when the correlation between rounded spermatids and Sertoli cells is high, spermatic 
production is also high. The lowest reason obtained may be because of the low spermatogenic potential of the animal, and because the Sertoli cells are responsible for the nutrition and physical protection of germinative lineage cells in addition to facilitating their development, division, and differentiation into spermatozoa.

The number of Sertoli cells per testicle and the size of the testicle may be considered as principal factors for determining spermatic production of an animal. Sertoli cells are highly important for this process and lower number of Sertoli cells can be one of the factors that can decrease spermatogenic yield (França et al., 2005).

The average of total number of Sertoli cells (NSCT) found in this study $\left(4.15 \pm 0.94 \times 10^{9}\right)$ is higher than the value expected in small ruminants according to previous reports. Oliveira et al. (2015) observed $2.4 \pm 0.004 \times 10^{9} \quad$ NSCT and $2.2 \pm 0.004 \times 10^{9} \mathrm{NSCT}$ in breeding goat fed with and without supplementation of castor bean cake, respectively; Martins et al. (2008) observed $2.2 \pm 0.8 \times 10^{9}$ NSCT in SRD sheep. Similarly, the observed total number of Sertoli cells per testicular gram (NSCT/g; $34.52 \pm 11.44 \times 10^{6}$ ) was superior to that reported by Leal et al. (2004) $21.4 \times 10^{6}$ and Oliveira et al. (2015) $24.3 \pm 0.4 \times 10^{6}$ in goats. The higher number of Sertoli cells per testicular gram, which consequently influences spermatogenic yield, is an indicator of spermatogenic potential in the studied animals.

To evaluate daily spermatic production, various methods have been used; however, in this study, the method used is based in the testicular histology analysis, which requires the knowledge of SEC duration in sheep. The SEC duration of adult thrown sheep was reported to be 10.5 days (Cardoso \& Queiroz, 1988). In the present study, the observed daily spermatic production (DSP) corroborates the results of Oliveira et al. (2015), i.e., $3.6 \pm 0.05 \times 10^{9}$ DSP in the animal group supplemented with castor bean cake and $3.5 \pm 0.06 \times 10^{9}$ DSP in the animal group without supplementation. The daily spermatic production per testicular gram (DSP/g) is within the expected range observed in the sheep species; according to França \& Russell (1998), sheep, in addition to domestic animals such as pig, equine and rabbit, are classified as species with high spermatogenic efficiency, and daily spermatic production per testicular gram is about twenty to thirty million spermatozoa.

The testicular spermatic reserve is calculated from the rounded spermatids population in stage 1 of the SEC, because spermatozoa loss during the spermatids differentiation phase is insignificant. The mean testicular spermatic reserve (TRS) $\left(31.82 \pm 12.7 \times 10^{9}\right)$ was superior to that observed by Cardoso \& Queiroz (1988), i.e., $\quad 11.2 \pm 6.6 \times 10^{9} \quad$ TSR. While quantitative testicular histology was used in the present study, Cardoso \& Queiroz (1988) used the method of hemocytometry to evaluate spermatozoa in homogenates of testicles. The testicular spermatic reserve per testicular gram $(\mathrm{TRS} / \mathrm{g})\left(238.28 \pm 54.77 \times 10^{6}\right)$ is observed to be within the expected range, which, according to França \& Russell (1998), in most domestic animals lies between 120 and $260 \times 10^{6}$. Similarly, Cardoso \& Queiroz (1988) found $111.4 \pm 44.6 \times 10^{6}$ spermatozoa per testicular gram in their study.

There are few reports on effects of using detoxified castor bean cake in animal feed, especially on spermatogenesis. However, some studies evaluated the 
reproductive performance of females and suggested that using detoxified castor bean cake does not change the reproductive performance in sheep and goats (Silva et al., 2014; Silva et al., 2015). These reports corroborate the results of present study, which showed that using detoxified castor bean cake did not affect spermatogenesis in sheep.

In conclusion, the soybean meal in sheep diet can be completely replaced $(100 \%)$ with detoxified castor bean cake, because it does not affect spermatogenesis. However, it is suggested that further studies on seminal aspects should be carried out.

\section{REFERENCES}

AMANN, R.P., ALMQUIST, J.O. Reproductive Capacity of Dairy Bulls. VIII. Direct and Indirect Measurement of Testicular Sperm Production.

Journal of Dairy Science, v.45, n.6, p.774-781, 1962.

AZEVEDO, M.H.F.; PAULA, T.A.R.; MATTA, S.L.P.; FONSECA, C.C.; COSTA, E.P.; COSTA, D.S.; PEIXOTO, J.V. Cell population indexes of spermatogenic yield and testicular sperm reserves in adult jaguars (Panthera onca). Animal

Reproduction Science, v. 118, n.1, p.83-88, 2010.

BILLIG, H., FURUTA, I., RIVIER, C., TAPANAINEN, J., PARVINEN, M., HSUEH, A.J. Apoptosis in testis germ cells, developmental changes in gonadotoropin dependence and localization to selective tubule stages.

Endocrinology, v.136, n.1, p.5-12, 1995.
CARDOSO, F.M., QUEIROZ, G.F. Duration of the cycle of the seminiferous epithelium and daily sperm production of brazilian hairy rams. Animal Reproduction Science, v.17, n.1-2, p.77-84, 1988.

FRANÇA, L.R., AVELAR, G.F., ALMEIDA, F.F.L. Spermatogenesis and sperm transit through the epididymis in mammals with emphasis on pigs. Theriogenology, v.63, n.2, p.300-318, 2005.

FRANÇA, L.R., RUSSELL, L.D. The testis of domestic animals. In:

Regadera, J., Martinez-Garcia, F. (Eds.), Male Reproduction: A Multidisciplinary Overview. Churchill Livingstone, Madrid, ES, pp. 197-219, 1998.

GOMES, F.H.T., CÂNDIDO, M.J.D., CARNEIRO, M.S.D.S., FURTADO, R.N., PEREIRA, E.S. Consumo, comportamento e desempenho em ovinos alimentados com dietas contendo torta de mamona. Revista Ciência Agronômica, v.48, n.1, p.182-190, 2017.

HOCHEREAU-DE REVIERS, M.T., LINCOLN, G.A. Seasonal variation in the histology of the testis of the red deer, Cervus elaphus. Journal of Reproduction and Fertility, v.54, n.2, p.209-213, 1978.

INMET - Instituto Nacional de Meteorologia. Disponível em: http://www.inmet.gov.br. Acesso em 18 Junho de 2017.

JOHNSON, L., VARNER, D.D., ROBERTS, M.E., SMITH, T.L., KEILLOR, G.E., SCRUTCHFIELD, W.L. Efficiency of spermatogenesis: a 
comparative approach. Animal

Reproduction Science, v.60-61, p.471480, 2000.

LEAL, M.C., BECKER-SILVA, S.C., CHIARINI-GARCIA, H., FRANÇA, L.R. Sertoli cell efficiency and daily sperm production in goats (Capra hircus). Animal Reproduction, v.1, n.1, p.122-128, 2004.

MARTINS, J. A., SOUZA, C.E.A., CAMPOS, A.C.N., AGUIAR, G.V., LIMA, A.C.B., ARAÚJO, A.A., NEIVA, J.N.M., MOURA, A.A.A. Biometria do trato reprodutor e espermatogênese em ovinos sem padrão racial definido (SPRD). Archivos Zootecnia, v.57, n.220, p.553-556, 2008.

MORAIS, A.C.T.; BALARINE, M.K.; MENEZES, T.P.; FERRAZ, F.S.; GOMES, M.L.M.; MORAIS, D.B.; PAULA, T.A.R.; MATTA, S.L.P. Germ cells and the seminiferous epithelium cycle in the wild rodent Oxymycterus rufus (Rodentia: Cricetidae). Journal of Pharmacy and Biological Sciences, v. 11, n.4, p.61-71, 2016.

NRC- National Research Council. 2007. Nutrient requirements of small ruminants. p. 362.

OLIVEIRA, A.S., CAMPOS, J.M.S., OLIVEIRA, M.R.C., BRITO, A.F., VALADARES-FILHO, S.C., DETMANN, E., VALADARES, R.F.D., SOUZA, S.M. Nutrient digestibility, nitrogen metabolism and hepatic function of sheep fed diets containing solvent or expeller castor seed meal treated with calcium hydroxide. Animal Feed Science and
Technology, v.158, n.1-2, p.15-28, 2010 .

OLIVEIRA, C.H.A., SILVA, A.M., SILVA, L.M., VAN TILBURG, M.F., FERNANDES, C.C., VELHO, A.L., MOURA, A.A., MORENO, F.B., MONTEIRO-MOREIRA, A.C., MOREIRA. Growth, testis size, spermatogenesis, semen parameters and seminal plasma and sperm membrane protein profile during the reproductive development of male goats supplemented with de-oiled castor cake. Reproductive Toxicity, v.53, p.152161, 2015.

SANTOS, A.B., PEREIRA, M.L.A., OLIVEIRA SILVA, H.G., CARVALHO, G.G.P., DE JESUS PEREIRA, T.C., RIBEIRO, L.S.O., AZEVÊDO, J.A.G., SILVA, M.G.C.P.C., SOUSA, L.B., SOUSA, L.B. Intake, digestibility and performance of lambs fed diets containing peach palm meal. Tropical Animal Health and Production, v.48, p.509-515, 2016.

SILVA, L.M., OLIVEIRA, C.H.A., SILVA, C.M.G., SILVA, A.M., FERNANDES, C.C.L., FURTADO, R.F., NUNES-PINHEIRO, D.C.S., GUEDES, M.I.F., RONDINA, D. Use of castor meal (Ricinus communis L.) as a source of dietary protein in goats during the mating period: impact on reproductive and metabolic responses. Semina: Ciências Agrárias, v.36, n.1, p.203-216, 2015.

SILVA, L.M., SILVA, A.M., OLIVEIRA, C.H.A., CARNEIRO, H.A.V., SOUZA, P.T., BESERRA, F.J., SILVA, C.M.G., RONDINA, D. Reproductive responses and productive 
characteristics in ewes supplemented with detoxified castor meal for a long period. Revista Brasileira de

Zootecnia, v.43, n.8, p.419-427, 2014.

SOUSA, N.L., CABRAL, G.B., VIEIRA, P.M., BALDONI, A.B., ARAGÃO, F.J. Bio-detoxification of ricin in castor bean (Ricinus communis L.) seeds. Scientific Reports, v.7, p.19, 2017.

SOUZA, L.M., CARVALHO, L.P., ARAÚJO, J.S., MELO, E.J.T., MACHADO, O.L.T. Cell toxicity by ricin and elucidation of mechanism of Ricin inactivation. International Journal of Biological Macromolecules, v.113, p.821-828, 2018. 